\title{
The effect of growing conditions and the year of reproduction on sowing qualities of seeds, morphological and physiological characteristics in sprouts of Vigna radiata (L.) R. Wilczek
}

DOI: $10.30901 / 2227-8834-2020-2-73-86$

УДК 631.531:581.142:633.33

Поступление/Received: 06.04.2020

Принято/Accepted: 09.06.2020

\section{A. V. SUSHKEVICH, 0. N. ZABEGAEVA, M. 0. BURLYAEVA*}

N.I. Vavilov All-Russian Institute

of Plant Genetic Resources,

42, 44 Bolshaya Morskaya Street,

St. Petersburg

190000, Russia

*@m.burlyaeva@vir.nw.ru

Background. Mung bean (Vigna radiata (L.) R. Wilczek) sprouts are of high nutritional value and are very popular in the world, as they are a source of nutrients and bioactive compounds. In Russia, the consumption of $V$. radiata sprouts is only beginning to develop. Growing this crop for microgreens on a commercial scale requires cultivars with a rapid development rate and higher weight of sprouts. With this in view, the aim of this research was to study the effect of growing conditions and the genotype on morphological and physiological parameters of mung bean seeds and sprouts. Methods. Mung bean accessions from the VIR collection were analyzed. Germination energy, seed germination and seed vigor, and morphological characteristics were evaluated in seeds and sprouts of 16,000 plants. Four plant reproductions grown at Astrakhan (2015, 2017), Kuban (2005) and Adler (2016) Experiment Stations of VIR were studied. The effect produced by growing conditions and the genotype on morphological and physiological parameters of plants was identified using one- and two-way analyses of variance. Correlations between the traits were assessed using correlation and component analyses. Results. Specific individual features of the accessions produced the strongest effect on morphological and physiological characteristics of seeds and sprouts; weather conditions, the place and year of reproduction, to a lesser extent. Sowing quality of seeds depended more on the precipitation amount during the growing season than on the sum of active temperatures. When formed under dry conditions, seeds manifested better seed germination, germination energy of seeds, and seed vigor. Accessions with high and stable levels of seed germination, germination energy, and seed vigor, and weight of sprouts were identified.

Key words: mung bean, seed germination, germination energy of seeds, seed vigor, effect of ecogeographic conditions, variability of morphological characters.
Влияние условий выращивания и года репродукции на посевные качества семян и морфофизиологические показатели проростков Vigna radiata (L.) R. Wilczek

\section{А. В. СУШКЕВИЧ, О. Н. ЗАБЕГАЕВА, М. О. БУРЛЯЕВА*}

Федеральный исследовательский центр Всероссийский институт генетических ресурсов растений имени Н.И. Вавилова, 190000 Россия, г. Санкт-Петербург, ул. Б. Морская, 42, 44 * m.burlyaeva@vir.nw.ru

Актуальность. Проростки маша (Vigna radiata (L.) R. Wilczek) отличаются высокой пищевой ценностью и очень популярны в мире, так как являются источником питательных и биологически активных веществ. В России употребление в пищу проростков V. radiata только начинает развиваться. Для выращивания этой культуры на микрозелень в производственных условиях необходимо иметь сорта, характеризующиеся быстрым развитием и большим весом ростков. В связи с этим целью нашей работы стало изучение влияния условий выращивания и генотипа на морфофизиологические показатели семян и проростков. Методы. Исследованы образцы из коллекции маша ВИР. Проведена оценка энергии прорастания, всхожести, силы роста, морфологических признаков семян и проростков у 16000 растений. Изучены семена четырех репродукций - Астраханской (2015, 2017 г.), Кубанской (2005 г.) и Адлерской (2016 г.) опытных станций ВИР. Влияние условий выращивания и генотипа на морфофизиологические показатели устанавливали с помощью одно- и двухфакторного дисперсионного анализа. Изучение взаимосвязей между признаками проводили с применением корреляционного и компонентного анализов. Результаты. Наиболее сильно на морфофизиологические признаки семян и проростков действуют индивидуальные особенности образцов, слабее - погодные условия, место и год репродукции. Посевные качества семян больше зависят от числа осадков, выпавших во время вегетации, чем от суммы активных температур. В сухих условиях формируются семена с лучшей всхожестью, энергией прорастания и силой роста. Выделены образцы, имеющие стабильные и высокие показатели энергии прорастания, всхожести, силы роста и веса проростков.

Ключевые слова: маш, энергия прорастания, всхожесть, сила роста семян, влияние эколого-географических условий, изменчивость морфологических признаков.

\section{Introduction}

Mung bean (Vigna radiata (L.) R. Wilczek) is a multipurpose crop, widespread in the countries of Southeast Asia and in the arid regions of Africa and Australia. In the Russian Federation it has been cultivated on small areas in the southern parts of the country. This crop is grown for seeds, sprouts and beans, used to prepare porridge, soups, or vegetable ac- companiments. Mung bean dishes enrich the human diet not only with proteins, carbohydrates or micronutrients, but also with essential amino acids, such as lysine, known to be deficient in cereals (Shi et al., 2016). Nutritive value is found not only in seeds, but also in sprouts: because of their low glycemic index they are often used in various diets. Like seeds, they are a source of numerous nutrients. They contain flavonoids, phenolic acids, organic acids, amino acids, carbohydrates, and 
lipids. Metabolites in mung bean sprouts are biologically active and possess antioxidant, antimicrobial, anti-inflammatory, antidiabetic, antihypertensive, antitumor and other healthfriendly properties. That is why ordinary food prepared from mung bean seeds or sprouts is regarded and used as a medication (Tang et al., 2014, Ullah et al., 2014).

Mung bean sprouts (microgreens) are a very popular food among both Europeans and Americans because it serves as a source of minerals and vitamins and its production does not require much acreage, inputs or time (Ebert, 2015; Kyriacou et al., 2016). Sprouts are sold fresh or canned (Pataczek et al., 2018). From 2014 through 2018, the total imports of mung bean seeds to Europe to produce sprouts have been 21-27 million tons (Market Access Database, 2018). In 2017, the main suppliers were Myanmar (14.4 million tons), China (3.8), and Australia (1.8)

In Russia, mung bean sprouts have only recently started to be part of the diet. To cultivate $V$. radiata on a large scale for microgreen production, it is essential to have cultivars with high plant growth vigor, rapid development rate, and ability to produce large amounts of sprouts.

Seeds with high sowing qualities are quicker to form sprouts. Seed vigor is associated with the growth, development and productivity of plants grown from them (Likhachev, 1984). It is known that seed germination, germination energy of seeds, and seed vigor in many pulse crop seeds depends on cultivar-specific differences and growing conditions (Adamova, 1971a; Likhachev, Shevchenko, 1975; Rakovskaya et al., 2019).

Considering all this, the aim of our research was to analyze the effect produced by seed growing conditions, periods of seed conservation, and specific features of varieties (genotype) on the indicators of seed germination, germination energy, and seed vigor as well as on morphological characters of mung bean sprouts.

The research objectives included:

1. studying the variability in germination energy, seed germination, and seed vigor when seed accessions were reproduced under different ecogeographic conditions;
2. assessing the variability of morphological and agronomic characteristics in sprouts (in the phase of first leaf development) grown from seeds in different sites of reproduction

3. analyzing the effect of the genotype, weather conditions, place and year of seed reproduction on the studied indicators in seeds and sprouts;

4. identifying mung bean accessions with high and stable levels of the development (growth) and weight of sprouts.

\section{Materials and methods}

The accessions of Kenyan origin from the mung bean collection held by the N.I. Vavilov Institute of Plant Genetic Resources (VIR) served as the material for our experiments. The seeds selected for the study were grown under different ecogeographic conditions at three branch stations of VIR: Kuban Experiment Station (KES) in 2005; Astrakhan Experiment Station (AES) in 2015 and 2017; and Adler Experiment Station (AdES) in 2016.

The areas where the seeds were reproduced differed in their soil and climate environments. AES is situated in Astrakhan Province, in the area of insufficient humidity. Soils on the experimental plot are alluvial-meadow heavy loams. The summer is hot and dry. The sum of active temperatures in 2015 was $3945.5^{\circ} \mathrm{C}$; in $2017,3915.7^{\circ} \mathrm{C}$; precipitation amount from April to October in 2015 was $92.8 \mathrm{~mm}$; in 2017, $103.0 \mathrm{~mm}$ (Fig. 1). KES is located in the steppe area of the Kuban Plain, Krasnodar Territory. Soils in the station's zone are represented by massive Ciscaucasian chernozems developed on forest-like loam carbonate. The climate in the station's vicinity is warm, moderately continental, with hot summers, insufficient humidity, and extreme instability in all climatic data elements. In 2005, the sum of active temperatures reached $3751.4^{\circ} \mathrm{C}$; precipitation amount from April to October was $346.8 \mathrm{~mm}$. AdES is situated in Adlersky District, City of Sochi, on the shore of the Black Sea. The earth in the vicinity is represented by yellow and red soils. The climate in the station's area is humid sub-

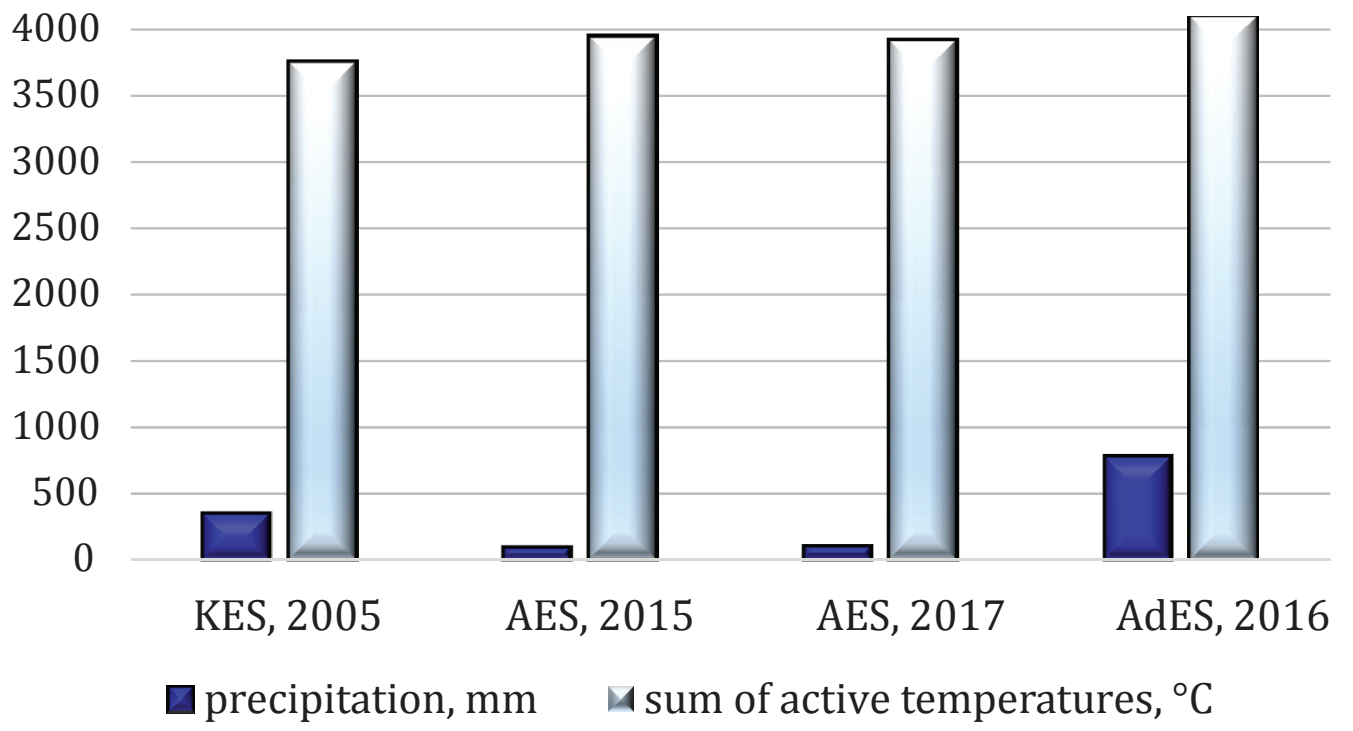

Fig. 1. The sums of active temperatures and precipitation amounts during the growing season in the years of seed reproduction at the Experiment Stations of VIR: KES - Kuban Experiment Station, AES - Astrakhan Experiment Station, AdES - Adler Experiment Station

Рис. 1. Сумма активных температур и количество осадков, выпавших за вегетационный период в годы размножения семян на опытных станциях ВИР. KES - Кубанская опытная станция, AES - Астраханская опытная станция, AdES - Адлерская опытная станция 
tropical, with a hot and humid climatic summer. The sum of active temperatures in 2016 was $4094.7^{\circ} \mathrm{C}$, with the precipitation amount from April to October $778.7 \mathrm{~mm}$.

Sums of active temperatures and precipitation amounts were calculated using the weather report data provided by the All-Russia Research Institute of Hydrometeorological Information - World Data Center (RIHMI-WDC, 2020).

Germination energy of seeds and seed germination were measured according to the guidelines approved for grain legume crops (GOST 12038-84). Seeds were germinated in rolls under laboratory conditions at a constant temperature of $+20^{\circ} \mathrm{C}$. They were placed on two layers of filter paper sized $20 \times 100 \mathrm{~cm}( \pm 2 \mathrm{~cm}), 5 \mathrm{~cm}$ below the upper edge of a sheet. From above, the sample was covered with a band of moistened filter paper of the same size. Then, the seeds placed between paper layers were rolled up into a roll and inserted vertically into a seed germinator. Seed vigor was analyzed on the basis of B.S. Likhachev's technique developed for cereal crops (Likhachev, 1975). Seed germination energy indicators were recorded on the 4th day, seed vigor on the 5 th, seed germination and seed hardness on the 10 th. Germination energy, seed germination, and seed vigor were calculated in percent form. Morphological characters of the sprouts (their wet and dry weight, lengths of the root, stem and first leaf, stem diameter) were examined on the 10th day. For each accession of the collection, 1600 plants were analyzed (100 seeds in 4 replications from each reproduction). All in all, 16,000 plants were evaluated.

Statistical processing of the data obtained was performed using the software package Statistica 10.0 (http:// statsoft.ru). To study the relationships between characters, correlation analysis was applied ( $r=$ the Pearson correlation coefficient). The following scale was accepted for correlation coefficients: very strong, $r>0.90$; strong, $0.90>r>0.70$; medium, $0.70>r>0.50 ;$ and weak, $0.50>r>0.30$. Factor analysis (employing principal components) was applied to disclose the variability and structure of relationships among characters.

Statistical significance of the effect produced by the genotype, weather conditions and reproduction sites on the studied characteristics was determined using one-way and two-way analyses of variance. Following Fisher's model, the percent of the factor's effect size $\left(\eta^{2}, \%\right)$ was calculated according to the formula (Ivanter, Korosov, 2003):

$$
\eta^{2}=\frac{S S_{\text {factor }}}{S S_{\text {total }}} \times 100 \%
$$

where $\eta^{2}, \%$ is the effect size percentage; $\mathrm{SS}_{\text {factor }}$ is the sum of squared deviations for a factor; $\mathrm{SS}_{\text {total }}$ is the total sum of squared deviations.

\section{Results and discussion}

Our research has shown that the mung bean accessions from Kenya demonstrate high variability in their growth and development indicators in the early stages of plant ontogenesis (Table 1). Strong variations were observed in morphological (root length, stem length, leaf length, and stem diameter) and agronomic (1000 seed weight, and sprout weight) characters as well as in physiological ones (germination energy of seeds, seed germination, and seed vigor).

Table 1. Variability of plant growth and development indicators in the early stages of ontogenesis in the accessions of Vigna radiata at the Kuban, Astrakhan, and Adler Experiment Stations of VIR (2005, 2015-2017)

Таблица 1. Изменчивость показателей роста и развития растений на ранних стадиях онтогенеза у образцов Vigna radiata на Кубанской, Астраханской и Адлерской опытных станциях ВИР (2005, 2015-2017 гг.)

\begin{tabular}{|l|c|c|c|}
\hline \multicolumn{1}{|c|}{ Indicator } & Minimum value & Maximum value & $\begin{array}{c}\text { Mean value, } \\
\text { error of the mean }\end{array}$ \\
\hline Germination energy of seeds, \% & 18.00 & 100.00 & $75.89 \pm 0.78$ \\
\hline Seed germination, \% & 22.00 & 100.00 & $80.31 \pm 0.70$ \\
\hline Seed vigor, \% & 0.00 & 96.00 & $3.22 \pm 0.22$ \\
\hline Seed hardness, \% & 0.00 & 30.00 & $50.83 \pm 0.87$ \\
\hline 1000 seed weight, g & 24.00 & 138.00 & $0.34 \pm 0.01$ \\
\hline Wet sprout weight, g & 0.13 & 0.60 & $0.03 \pm 0.0004$ \\
\hline Dry sprout weight, g & 0.01 & 0.06 & $8.51 \pm 0.01$ \\
\hline Sprout stem length, cm & 2.80 & 17.60 & $11.67 \pm 0.12$ \\
\hline Sprout root length, cm & 2.00 & 19.20 & $2.48 \pm 0.03$ \\
\hline Sprout stem diameter, mm & 1.00 & 5.00 & 0.14 \\
\hline First leaf length, cm & 0.50 & 3.10 & \\
\hline
\end{tabular}


The studied characters varied greatly across the places of seed reproduction (Fig. 2). Practically all measured indicators showed the best values in the seeds and sprouts produced in Astrakhan Province (AES). Those accessions had the highest germination energy, seed germination, and seed vigor. They also exceeded accessions grown at other sites in the weight of wet sprouts, stem and root lengths, but in the first leaf length they were the best only in 2015. Seeds re- produced at the Kuban Experiment Station had the highest weight of 1000 seeds, but the sprouts germinated from them demonstrated lower values of root, stem and leaf length, and wet sprout weight. The exceptions were stem diameter and dry sprout weight: these indicators showed higher values than in the sprouts grown from the seeds of other reproductions. The worst values were observed in the seeds and sprouts produced in Adler (AdES).
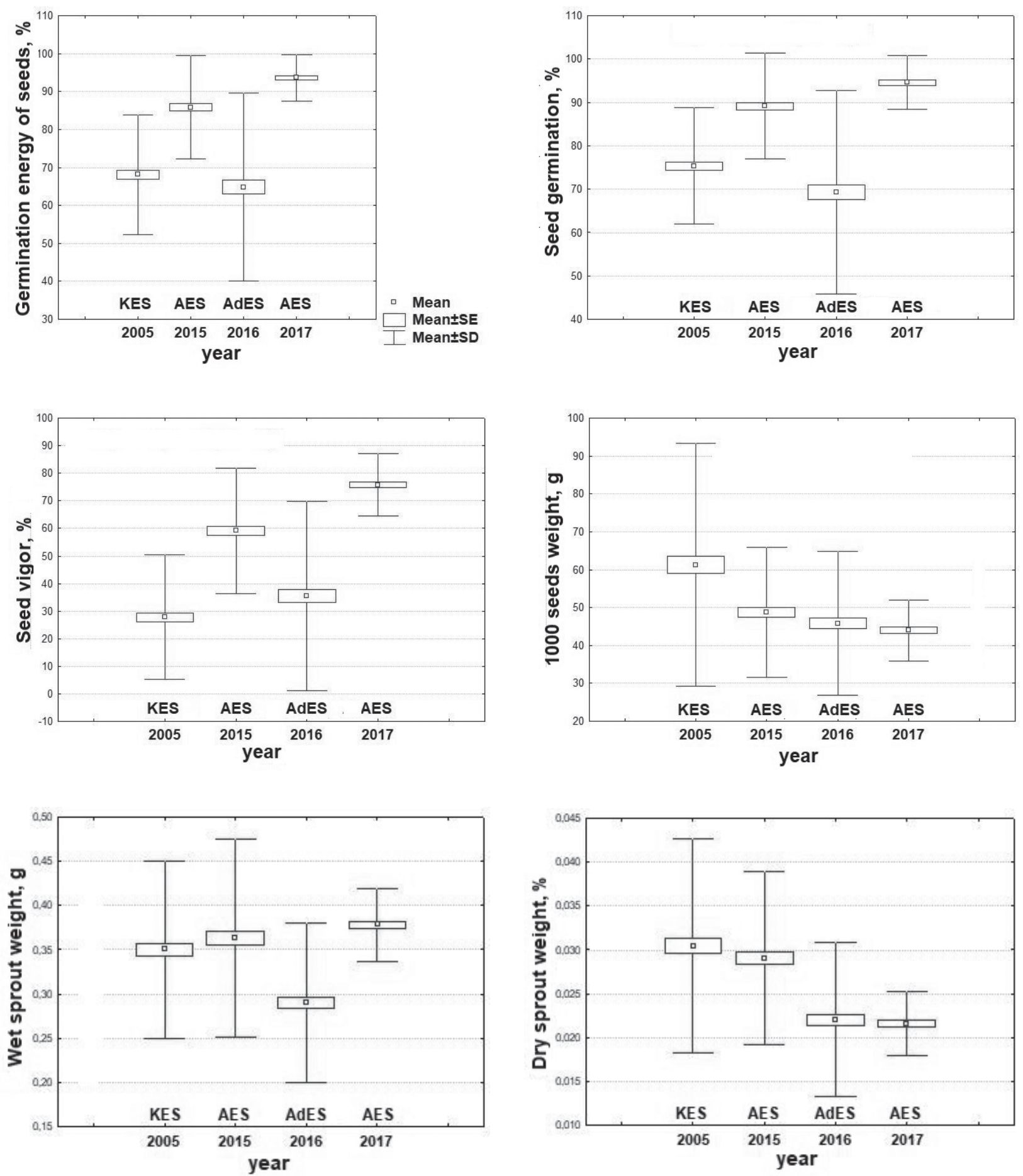

Fig. 2. Variability of growth and development indicators in the sprouts of Vigna radiata grown from seeds reproduced in different soil and climate environments

Рис. 2. Изменчивость показателей роста и развития проростков Vigna radiata, выращенных из семян, репродуцированных в разных почвенно-климатических условиях 

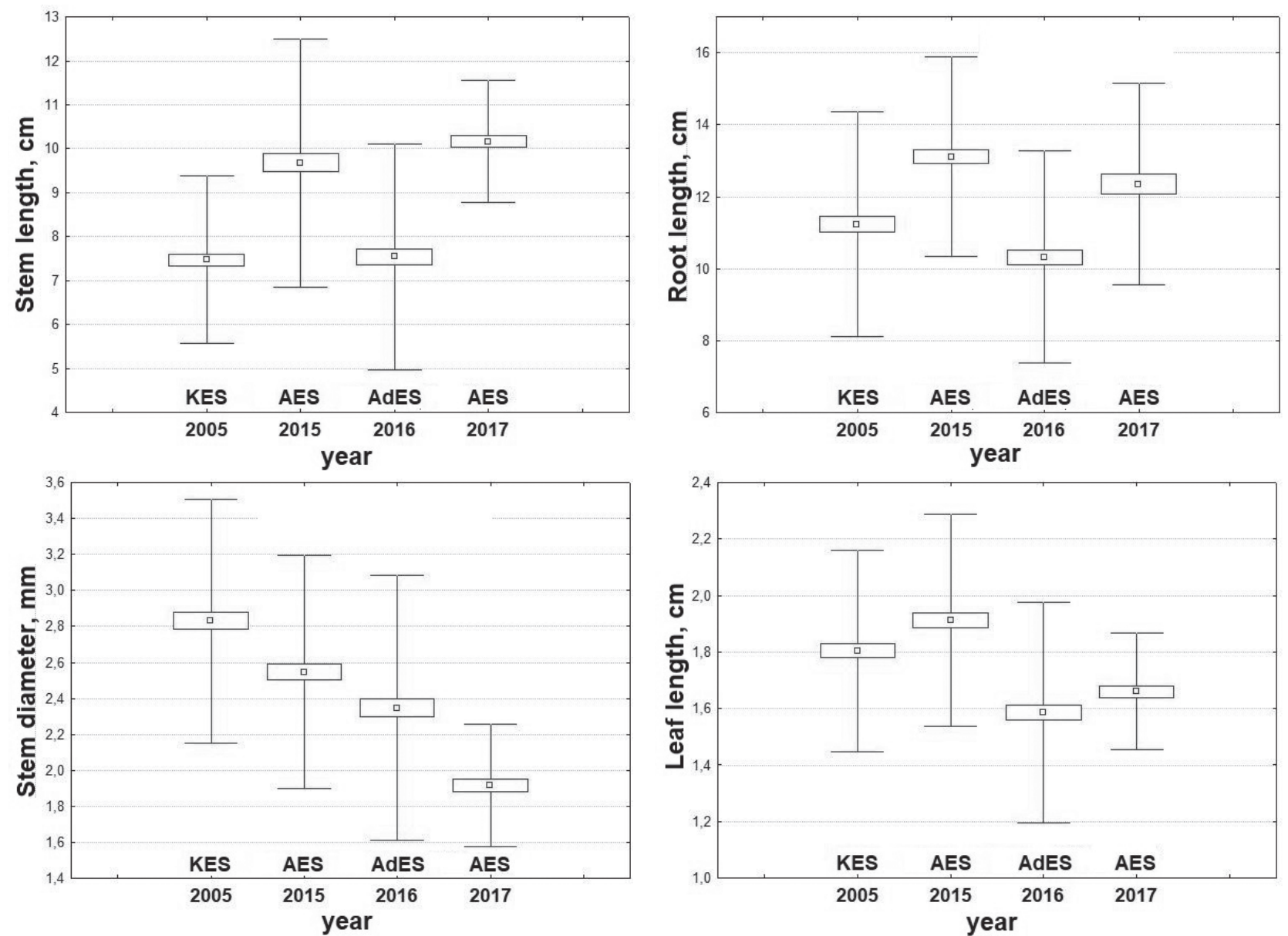

Fig. 2. Variability of growth and development indicators in the sprouts of Vigna radiata grown from seeds reproduced in different soil and climate environments

Рис. 2. Изменчивость показателей роста и развития проростков Vigna radiata, выращенных из семян, репродуцированных в разных почвенно-климатических условиях

In our experiment, significant differences in morphological, biological and agronomic characteristics were registered between different accessions as well (Table 2).

The best mean values (calculated for all versions of the experiment) of germination energy and seed germination were found in accessions k-14436, k-14401, k-14408 and $\mathrm{k}-14451$, while $\mathrm{k}-14407, \mathrm{k}-14436$ and $\mathrm{k}-14403$ were the best in seed vigor. Among those accessions k-14407 deserves a special mention as it stably demonstrated good seed growth values regardless of the year or place of seed reproduction. The highest seed hardness was observed in $\mathrm{k}$-14416; the same accession showed low levels of germination energy, seed germination, and seed vigor. An analogous pattern of the abovementioned indicators was obvious in $\mathrm{k}-14421$. High values of root length were identified in accessions k-14408, k-14436 and k-14438; stem length, in k-14408; leaf length, in k-14408, k-14438 and k-14403; stem diameter, in k-14401, k-14438 and k-14403; wet sprout weight, in $\mathrm{k}-14408, \mathrm{k}-14438, \mathrm{k}-14403$ and $\mathrm{k}-14436$; dry sprout weight, in $\mathrm{k}-14408$ and $\mathrm{k}-14403$. The best accessions in the entire set of indicators were k-14408, k-14403 and k-14438.

To check the significance of the effect produced by the genotype, place and year of reproduction, and weather conditions on the tested indicators, factorial analysis of variance was applied (Tables 3-6). Its results showed that the variability of the studied characters was significantly affected by all the factors in question. Seed hardness, howev- er, did not depend on the site of seed reproduction. In our experiment, this indicator was stronger influenced by the genotype (effect size $\eta^{2}=42 \%$ ), and to a lesser extent by the year of seed reproduction $\left(\eta^{2}=1 \%\right)$.

Two-way analysis of variance, undertaken to disclose associations between the year of seed reproduction and the genotype, and the variability of morphological and agronomic characters, showed that the latter were more affected by the genome of an accession than the year of its reproduction (Table 3). The effect size of the genotype, produced on 1000 seed weight, was 58\%; on wet and dry sprout weight, 65 and 57\%, respectively; on root, leaf and stem lengths, 33, 31 and 34\%, respectively; on stem diameter, $25 \%$. The genotype and the year of seed reproduction had almost the same effect on the variability of sowing quality indicators in mung bean seeds (germination energy, seed germination, and seed vigor): their effect size varied within the range of 24 to $36 \%$.

According to the results of a one-way analysis of variance, the site of seed reproduction rendered an effect on the growth indicators of seeds and sprouts in a similar way as with the year of their reproduction (Table 4). Tukey's test showed that soil and climate conditions at AdES and KES had an almost similar effect on the studied indicators, while AES was significantly different. In the context of the analyzed set of morphological and physiological characters, the seeds delivered from Astrakhan Province were much better 
Table 2. Characterization of Vigna radiata accessions according to mean values of their growth and development indicators in the early stages of ontogenesis at the Kuban, Astrakhan, and Adler Experiment Stations of VIR (2005, 2015-2017)

Таблица 2. Характеристика образцов Vigna radiata по средним показателям роста и развития растений на ранних стадиях онтогенеза на Кубанской, Астраханской и Адлерской опытных станциях ВИР (2005, 2015-2017 гг.)

\begin{tabular}{|c|c|c|c|c|c|c|c|c|c|c|c|}
\hline 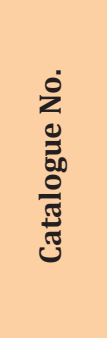 & 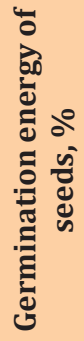 & 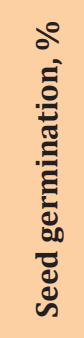 & 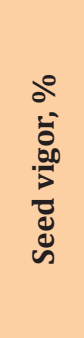 & 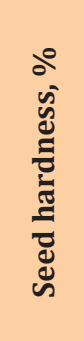 & 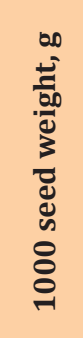 & 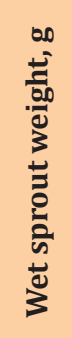 & 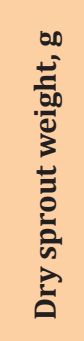 & 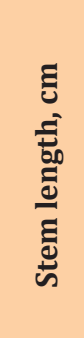 & 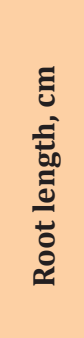 & 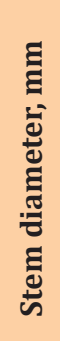 & 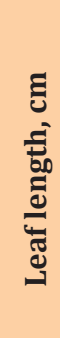 \\
\hline 14401 & 86.3 & 87.8 & 21.8 & 0.2 & 39.6 & 0.3 & 0.03 & 6.8 & 10.8 & 3.3 & 1.8 \\
\hline 14403 & 69.8 & 79.0 & 64.7 & 0.1 & 60.2 & 0.4 & 0.04 & 6.5 & 8.6 & 2.8 & 1.9 \\
\hline 14405 & 79.7 & 85.0 & 35.3 & 0.3 & 48.3 & 0.3 & 0.03 & 7.9 & 10.1 & 2.7 & 1.8 \\
\hline 14407 & 78.8 & 82.7 & 76.7 & 7.5 & 34.5 & 0.3 & 0.02 & 9.2 & 13.4 & 2.5 & 1.8 \\
\hline 14408 & 84.2 & 90.0 & 60.8 & 0.9 & 94.0 & 0.5 & 0.04 & 11.6 & 14.1 & 2.7 & 2.2 \\
\hline 14412 & 79.9 & 82.4 & 44.6 & 3.0 & 70.0 & 0.3 & 0.02 & 8.9 & 12.9 & 2.3 & 1.5 \\
\hline 14416 & 47.5 & 52.7 & 26.0 & 14.9 & 51.3 & 0.2 & 0.02 & 6.5 & 12.4 & 2.0 & 1.5 \\
\hline 14421 & 64.8 & 69.5 & 33.5 & 5.9 & 35.5 & 0.3 & 0.02 & 7.7 & 9.6 & 2.1 & 1.4 \\
\hline 14436 & 95.5 & 96.5 & 68.0 & 1.5 & 60.0 & 0.4 & 0.02 & 10.3 & 14.1 & 2.0 & 1.8 \\
\hline 14438 & 75.3 & 79.5 & 33.7 & 0.0 & 34.7 & 0.5 & 0.03 & 10.3 & 13.6 & 2.9 & 1.9 \\
\hline 14451 & 84.4 & 88.0 & 57.8 & 0.9 & 40.4 & 0.3 & 0.03 & 9.1 & 11.3 & 2.1 & 1.8 \\
\hline
\end{tabular}

Table 3. Results of a two-way analysis of variance, disclosing associations between the year of seed reproduction and the genotype, and the variability of morphological and biological characters in Vigna radiata

Таблица 3. Результаты двухфакторного дисперсионного анализа по выявлению ассоциаций между годом репродукции семян, генотипом и изменчивостью морфологических и биологических признаков Vigna radiata

\begin{tabular}{|l|c|c|c|c|c|c|c|c|c|c|}
\hline \multicolumn{1}{|c|}{ Factors } & Df & SS & MS & F & p & SS & MS & F & p \\
\hline \multicolumn{3}{|c|}{} & \multicolumn{3}{|c|}{ Germination energy of seeds } & \multicolumn{4}{c|}{ germination } \\
\hline Genotype & 9 & 78132 & 7813 & 39.78 & 0.00 & 70746 & 7075 & 45.30 & 0.00 \\
\hline Year & 3 & 78467 & 26156 & 133.18 & 0.00 & 59200 & 19733 & 126.36 & 0.00 \\
\hline $\begin{array}{l}\text { Residual } \\
\text { variability }\end{array}$ & 686 & 134724 & 196 & & & 107128 & 156 & & \\
\hline $\begin{array}{l}\text { Total } \\
\text { variability }\end{array}$ & 699 & 300756 & & & & 243124 & & & \\
\hline$\eta_{\text {genotype }}^{2} \%$ & & 25.98 & & & & & 24.35 & & & \\
\hline$\eta_{\text {year }}^{2} \%$ & & 26.09 & & & & &
\end{tabular}


Table 3. The end

Таблица 3. Окончание

\begin{tabular}{|c|c|c|c|c|c|c|c|c|c|}
\hline Factors & Df & SS & MS & $\mathbf{F}$ & $\mathbf{p}$ & SS & MS & $\mathbf{F}$ & $\mathbf{p}$ \\
\hline & & \multicolumn{4}{|c|}{ Seed vigor } & \multicolumn{4}{|c|}{1000 seed weight } \\
\hline Genotype & 9 & 226834 & 22683 & 68.996 & 0.00 & 217927 & 21793 & 120.841 & 0.00 \\
\hline Year & 3 & 237043 & 79014 & 240.337 & 0.00 & 34650 & 11550 & 64.046 & 0.00 \\
\hline $\begin{array}{l}\text { Residual } \\
\text { variability }\end{array}$ & 686 & 225533 & 329 & & & 123715 & 180 & & \\
\hline $\begin{array}{l}\text { Total } \\
\text { variability }\end{array}$ & 699 & 663876 & & & & 373978 & & & \\
\hline$\eta_{\text {genotype }}^{2} \%$ & & 34.17 & & & & 58.27 & & & \\
\hline$\eta_{\text {year }}^{2} \%$ & & 35.71 & & & & 9.27 & & & \\
\hline & & \multicolumn{4}{|c|}{ Wet sprout weight } & \multicolumn{4}{|c|}{ Dry sprout weight } \\
\hline Genotype & 9 & 4.54774 & 0.45477 & 183.03 & 0.00 & 0.043590 & 0.004359 & 135.48 & 0.00 \\
\hline Year & 3 & 1.09719 & 0.36573 & 147.20 & 0.00 & 0.008128 & 0.002709 & 84.20 & 0.00 \\
\hline $\begin{array}{l}\text { Residual } \\
\text { variability }\end{array}$ & 686 & 1.70447 & 0.00248 & & & 0.022073 & 0.000032 & & \\
\hline $\begin{array}{l}\text { Total } \\
\text { variability }\end{array}$ & 699 & 7.01786 & & & & 0.076446 & & & \\
\hline$\eta_{\text {genotype }}^{2} \%$ & & 64.80 & & & & 57.02 & & & \\
\hline$\eta_{\text {year }}^{2} \%$ & & 15.63 & & & & 10.63 & & & \\
\hline & & \multicolumn{4}{|c|}{ Stem length } & \multicolumn{4}{|c|}{ Root length } \\
\hline Genotype & 9 & 1613.01 & 161.30 & 50.24 & 0.00 & 2251.74 & 225.17 & 41.55 & 0.00 \\
\hline Year & 3 & 958.62 & 319.54 & 99.52 & 0.00 & 907.62 & 302.54 & 55.83 & 0.00 \\
\hline $\begin{array}{l}\text { Residual } \\
\text { variability }\end{array}$ & 686 & 2202.66 & 3.21 & & & 3717.39 & 5.42 & & \\
\hline $\begin{array}{l}\text { Total } \\
\text { variability }\end{array}$ & 699 & 4770.26 & & & & 6831.78 & & & \\
\hline$\eta_{\text {genotype }}^{2} \%$ & & 33.81 & & & & 32.96 & & & \\
\hline$\eta_{\text {year }}^{2} \%$ & & 20.10 & & & & 13.29 & & & \\
\hline & & \multicolumn{4}{|c|}{ Stem diameter } & \multicolumn{4}{|c|}{ Leaf length } \\
\hline Genotype & 9 & 88.354 & 8.835 & 29.45 & 0.00 & 30.718 & 3.072 & 36.89 & 0.00 \\
\hline Year & 3 & 40.177 & 13.392 & 44.64 & 0.00 & 11.134 & 3.711 & 44.57 & 0.00 \\
\hline $\begin{array}{l}\text { Residual } \\
\text { variability }\end{array}$ & 686 & 205.791 & 0.300 & & & 57.127 & 0.083 & & \\
\hline $\begin{array}{l}\text { Total } \\
\text { variability }\end{array}$ & 699 & 354.990 & & & & 99.983 & & & \\
\hline$\eta_{\text {genotype }}^{2} \%$ & & 24.89 & & & & 30.72 & & & \\
\hline$\eta_{\text {year }}^{2} \%$ & & 11.32 & & & & 11.14 & & & \\
\hline
\end{tabular}

SS - sum of squares; MS - mean squares; F - Fisher criterion value; $p$ - significance level; df - degrees of freedom, $\eta^{2}, \%-$ effect size, percentage

SS - сумма квадратов, MS - среднеквадратичное отклонение, F - значение критерия Фишера, p - уровень значимости, $\mathrm{df}$ - числа степеней свободы, $\eta^{2}, \%$ - доля влияния 
Table 4. Results of a one-way analysis of variance, disclosing associations between the variability of morphological and biological characters in Vigna radiata and the site of seed reproduction

Таблица 4. Результаты однофакторного дисперсионного анализа по выявлению ассоциаций между изменчивостью морфологических и биологических признаков Vigna radiata и местом репродукции

\begin{tabular}{|c|c|c|c|c|c|c|c|c|c|}
\hline Factors & Df & SS & MS & $\mathbf{F}$ & $\mathbf{p}$ & SS & MS & $\mathbf{F}$ & $\mathbf{p}$ \\
\hline & & \multicolumn{4}{|c|}{ Germination energy of seeds } & \multicolumn{4}{|c|}{ Seed germination } \\
\hline $\begin{array}{l}\text { Place of } \\
\text { reproduction }\end{array}$ & 2 & 83864 & 41932 & 134.75 & 0.00 & 63276 & 31638 & 122.61 & 0.00 \\
\hline $\begin{array}{l}\text { Residual } \\
\text { variability }\end{array}$ & 597 & 216892 & 311 & & & 179847 & 258 & & \\
\hline $\begin{array}{l}\text { Total } \\
\text { variability }\end{array}$ & 599 & 300756 & & & & 243124 & & & \\
\hline$\eta^{2}, \%$ & & 27.88 & & & & 26.03 & & & \\
\hline & & \multicolumn{4}{|c|}{ Seed vigor } & \multicolumn{4}{|c|}{1000 seed weight } \\
\hline $\begin{array}{l}\text { Place of } \\
\text { reproduction }\end{array}$ & 2 & 193028 & 96514 & 142.870 & 0.00 & 30819 & 15410 & 31.299 & 0.00 \\
\hline $\begin{array}{l}\text { Residual } \\
\text { variability }\end{array}$ & 597 & 470848 & 676 & & & 343159 & 492 & & \\
\hline $\begin{array}{l}\text { Total } \\
\text { variability }\end{array}$ & 599 & 663876 & & & & 373978 & & & \\
\hline$\eta^{2}, \%$ & & 29.08 & & & & 8.24 & & & \\
\hline & & \multicolumn{4}{|c|}{ Wet sprout weight } & \multicolumn{4}{|c|}{ Dry sprout weight } \\
\hline $\begin{array}{l}\text { Place of } \\
\text { reproduction }\end{array}$ & 2 & 0.75041 & 0.37521 & 41.727 & 0.00 & 0.007069 & 0.003534 & 35.509 & 0.00 \\
\hline $\begin{array}{l}\text { Residual } \\
\text { variability }\end{array}$ & 597 & 6.26744 & 0,00899 & & & 0.069377 & 0.000100 & & \\
\hline Total variability & 599 & 7.01786 & & & & 0.076446 & & & \\
\hline$\eta^{2}, \%$ & & 10.69 & & & & 9.25 & & & \\
\hline & & \multicolumn{4}{|c|}{ Stem length } & \multicolumn{4}{|c|}{ Root length } \\
\hline $\begin{array}{l}\text { Place of } \\
\text { reproduction }\end{array}$ & 2 & 938.88 & 469.44 & 85.400 & 0.00 & 824.75 & 412.37 & 47.85 & 0.00 \\
\hline $\begin{array}{l}\text { Residual } \\
\text { variability }\end{array}$ & 597 & 3831.38 & 5.50 & & & 6007.04 & 8.62 & & \\
\hline Total variability & 599 & 4770.26 & & & & 6831.78 & & & \\
\hline$\eta^{2}, \%$ & & 19.68 & & & & 12.07 & & & \\
\hline & & \multicolumn{4}{|c|}{ Stem diameter } & \multicolumn{4}{|c|}{ Leaf length } \\
\hline $\begin{array}{l}\text { Place of } \\
\text { reproduction }\end{array}$ & 2 & 34.174 & 17.087 & 37.123 & 0.00 & 7.853 & 3.927 & 29.71 & 0.00 \\
\hline $\begin{array}{l}\text { Residual } \\
\text { variability }\end{array}$ & 597 & 320.815 & 0.460 & & & 92.130 & 0.132 & & \\
\hline $\begin{array}{l}\text { Total } \\
\text { variability }\end{array}$ & 599 & 354.990 & & & & 99.983 & & & \\
\hline$\eta^{2}, \%$ & & 9.63 & & & & 7.85 & & & \\
\hline
\end{tabular}


in their quality than those grown on the experimental fields of Krasnodar Territory.

The sum of active temperatures and the amount of precipitation during the growing season had a statistically significant effect on the variability of all tested characteristics of mung bean seeds and sprouts (Tables 5, 6). The effect of these two factors on seed germination energy, seed germination, and seed vigor was higher than on other characters: the effect size percentage varied from 27 to $32 \%$. Their effect on morphological and agronomic traits was $8-20 \%$. The

Table 5. Results of a one-way analysis of variance, disclosing associations between the variability of morphological and biological characters in Vigna radiata and the sum of active temperatures

Таблица 5. Результаты однофакторного дисперсионного анализа по выявлению ассоциаций между изменчивостью морфологических и биологических признаков Vigna radiata и суммой активных температур

\begin{tabular}{|c|c|c|c|c|c|c|c|c|c|}
\hline Factors & Df & SS & MS & $\mathbf{F}$ & $\mathbf{p}$ & SS & MS & $\mathbf{F}$ & $\mathbf{p}$ \\
\hline & & \multicolumn{4}{|c|}{ Germination energy of seeds } & \multicolumn{4}{|c|}{ Seed germination } \\
\hline $\begin{array}{l}\text { Sum of active } \\
\text { temperatures }\end{array}$ & 3 & 87817 & 29272 & 95.68 & 0.00 & 65090 & 21697 & 84.82 & 0.00 \\
\hline $\begin{array}{l}\text { Residual } \\
\text { variability }\end{array}$ & 696 & 212940 & 306 & & & 178034 & 256 & & \\
\hline Total variability & 699 & 300756 & & & & 243124 & & & \\
\hline$\eta^{2}, \%$ & & 29.20 & & & & 26.77 & & & \\
\hline & & \multicolumn{4}{|c|}{ Seed vigor } & \multicolumn{4}{|c|}{1000 seed weight } \\
\hline $\begin{array}{l}\text { Sum of active } \\
\text { temperatures }\end{array}$ & 3 & 212018 & 70673 & 108.857 & 0.00 & 33278 & 11093 & 22.661 & 0.00 \\
\hline $\begin{array}{l}\text { Residual } \\
\text { variability }\end{array}$ & 696 & 451858 & 649 & & & 340700 & 490 & & \\
\hline Total variability & 699 & 663876 & & & & 373978 & & & \\
\hline$\eta^{2}, \%$ & & 31.94 & & & & 8.90 & & & \\
\hline & & \multicolumn{4}{|c|}{ Wet sprout weight } & \multicolumn{4}{|c|}{ Dry sprout weight } \\
\hline $\begin{array}{l}\text { Sum of active } \\
\text { temperatures }\end{array}$ & 3 & 0.75513 & 0.25171 & 27.974 & 0.00 & 0.010591 & 0.003530 & 37.313 & 0.00 \\
\hline $\begin{array}{l}\text { Residual } \\
\text { variability }\end{array}$ & 696 & 6.26272 & 0.00900 & & & 0.065854 & 0.000095 & & \\
\hline Total variability & 699 & 7.01786 & & & & 0.076446 & & & \\
\hline$\eta^{2}, \%$ & & 10.76 & & & & 13.85 & & & \\
\hline & & \multicolumn{4}{|c|}{ Stem length } & \multicolumn{4}{|c|}{ Root length } \\
\hline $\begin{array}{l}\text { Sum of active } \\
\text { temperatures }\end{array}$ & 3 & 954.95 & 318.32 & 58.068 & 0.00 & 853.53 & 284.51 & 33.12 & 0.00 \\
\hline $\begin{array}{l}\text { Residual } \\
\text { variability }\end{array}$ & 696 & 3815.32 & 5.48 & & & 5978.25 & 8.59 & & \\
\hline Total variability & 699 & 4770.26 & & & & 6831.78 & & & \\
\hline$\eta^{2}, \%$ & & 20.02 & & & & 12.49 & & & \\
\hline & & \multicolumn{4}{|c|}{ Stem diameter } & \multicolumn{4}{|c|}{ Leaflength } \\
\hline $\begin{array}{l}\text { Sum of active } \\
\text { temperatures }\end{array}$ & 3 & 59.588 & 19.863 & 46.799 & 0.00 & 11.459 & 3.820 & 30.03 & 0.00 \\
\hline $\begin{array}{l}\text { Residual } \\
\text { variability }\end{array}$ & 696 & 295.402 & 0.424 & & & 88.524 & 0.127 & & \\
\hline Total variability & 699 & 354.990 & & & & 99.983 & & & \\
\hline$\eta^{2}, \%$ & & 16.79 & & & & 11.46 & & & \\
\hline
\end{tabular}


Table 6. Results of a one-way analysis of variance, disclosing associations between the variability of morphological and biological characters in Vigna radiata and the amount of precipitation

Таблица 6. Результаты однофакторного дисперсионного анализа по выявлению ассоциаций между изменчивостью морфологических и биологических признаков Vigna radiata и количеством осадков

\begin{tabular}{|c|c|c|c|c|c|c|c|c|c|}
\hline Factors & Df & SS & MS & $\mathbf{F}$ & $\mathbf{p}$ & SS & MS & $\mathbf{F}$ & $\mathbf{p}$ \\
\hline & & \multicolumn{4}{|c|}{ Germination energy of seeds } & \multicolumn{4}{|c|}{ Seed germination } \\
\hline $\begin{array}{l}\text { Precipitation } \\
\text { amount }\end{array}$ & 3 & 87900 & 29300 & 95.80 & 0.00 & 65249 & 21750 & 85.10 & 0.00 \\
\hline $\begin{array}{l}\text { Residual } \\
\text { variability }\end{array}$ & 696 & 212857 & 306 & & & 177874 & 256 & & \\
\hline Total variability & 699 & 300756 & & & & 243124 & & & \\
\hline$\eta^{2}, \%$ & & 29.23 & & & & 26.84 & & & \\
\hline & & \multicolumn{4}{|c|}{ Seed vigor } & \multicolumn{4}{|c|}{1000 seed weight } \\
\hline $\begin{array}{l}\text { Precipitation } \\
\text { amount }\end{array}$ & 3 & 211509 & 70503 & 108.474 & 0.00 & 32336 & 10779 & 21.959 & 0.00 \\
\hline $\begin{array}{l}\text { Residual } \\
\text { variability }\end{array}$ & 696 & 452366 & 650 & & & 341642 & 491 & & \\
\hline Total variability & 699 & 663876 & & & & 373978 & & & \\
\hline$\eta^{2}, \%$ & & 31.86 & & & & 8.65 & & & \\
\hline & & \multicolumn{4}{|c|}{ Wet sprout weight } & \multicolumn{4}{|c|}{ Dry sprout weight } \\
\hline $\begin{array}{l}\text { Precipitation } \\
\text { amount }\end{array}$ & 3 & 0.76565 & 0.25522 & 28.411 & 0.00 & 0.010783 & 0.003594 & 38.098 & 0.00 \\
\hline $\begin{array}{l}\text { Residual } \\
\text { variability }\end{array}$ & 696 & 6.25221 & 0.00898 & & & 0.065663 & 0.000094 & & \\
\hline Total variability & 699 & 7.01786 & & & & 0.076446 & & & \\
\hline$\eta^{2}, \%$ & & 10.91 & & & & 14.11 & & & \\
\hline & & \multicolumn{4}{|c|}{ Stem length } & \multicolumn{4}{|c|}{ Root length } \\
\hline $\begin{array}{l}\text { Precipitation } \\
\text { amount }\end{array}$ & 3 & 954.59 & 318.20 & 58.041 & 0.00 & 862.65 & 287.55 & 33.53 & 0.00 \\
\hline $\begin{array}{l}\text { Residual } \\
\text { variability }\end{array}$ & 696 & 3815.67 & 5.48 & & & 5969.14 & 8.58 & & \\
\hline Total variability & 699 & 4770.26 & & & & 6831.78 & & & \\
\hline$\eta^{2}, \%$ & & 20.01 & & & & 12.63 & & & \\
\hline & & \multicolumn{4}{|c|}{ Stem diameter } & \multicolumn{4}{|c|}{ Leaf length } \\
\hline $\begin{array}{l}\text { Precipitation } \\
\text { amount }\end{array}$ & 3 & 60.845 & 20.282 & 47.990 & 0.00 & 12.138 & 4.046 & 32.06 & 0.00 \\
\hline $\begin{array}{l}\text { Residual } \\
\text { variability }\end{array}$ & 696 & 294.145 & 0.423 & & & 87.846 & 0.126 & & \\
\hline Total variability & 699 & 354.990 & & & & 99.983 & & & \\
\hline$\eta^{2}, \%$ & & 17.14 & & & & 12.14 & & & \\
\hline
\end{tabular}


precipitation amount produced a little stronger effect on variations in wet and dry sprout weight, stem diameter, and root and leaf length. Correlation analysis identified weak negative correlations between precipitation amount and germination energy of seeds $(\mathrm{r}=-0.47)$, seed germination $(r=-0.46)$, seed vigor $(r=-0.40)$, wet sprout weight $(r=-0.30)$, stem length $(r=-0.39)$, and root length $(r=-0.35)$; correlation coefficients were weaker for all other characters $(r<0.30)$. The sum of active temperature correlated very weakly $(\mathrm{r}<0.30)$ with all morphological and physiological characters.

Interrelations among morphological and physiological characters were studied using correlation analysis (significance level $\mathrm{p}<0.05$ ). As a result, strong correlations were identified between germination energy of seeds and seed germination $(r=0.95)$, and dry and wet sprout weights $(r=0.70)$. Germination energy had medium correlations with a number of characters: seed vigor $(r=0.60)$, and sprout stem length $(r=0.58)$. The same correlation level was observed for seed germination with seed vigor $(r=0.58)$, wet sprout weight $(r=0.50)$, stem length $(r=0.57)$, and leaf length $(r=0.50)$. Seed vigor correlated with stem length $(r=0.56)$. Wet sprout weight correlated both with stem length $(r=0.56)$ and with leaf length $(r=0.59)$, while dry sprout weight only with leaf length $(r=0.59)$. Positive correlations were found between stem and root lengths $(r=0.61)$, and between stem and leaf lengths $(r=0.50)$. Negative correlations were observed for seed hardness with germination energy $(\mathrm{r}=-0.50)$ and seed germination $(r=-0.49)$. Thus, sowing qualities of seeds to a considerable extent determined the development of sprouts, while seed hardness reduced the seed germination and germination energy indicators. Maximum weight was measured in sprouts with long stems and leaves.

Factor analysis (employing principal components) was applied to disclose regularities in the variability and structure of links among characters in mung bean accessions in the early stages of ontogenesis (Table 7). Component analysis identified two factors that determined $59.0 \%$ of the total variance for characters. The first factor $\left(\mathrm{F}_{1}, 35 \%\right.$ of vari- ance) included: seed germination, germination energy, seed vigor, wet sprout weight, and stem, root and leaf lengths. Analyzing the first factor showed that the seeds with high values of seed germination, germination energy, seed vigor developed sprouts with a higher wet sprout weight, and longer stems, leaves and roots. This factor may be interpreted as the factor of seed germination energy and seed vigor. The second factor $\left(\mathrm{F}_{2}, 24 \%\right.$ of variance $)$ aggregated dry sprout weight, stem diameter, 1000 seed weight, and, in negative correlation, seed hardness. The leading characters within this factor, i.e., with the strongest effect on coordinated variations in the rest characters, were dry sprout weight and stem diameter. Studying the set of characters in the second factor revealed an interrelation between stem diameter and 1000 seed weight. Sprouts with a longer stem diameter germinated from larger seeds. Seed hardness was observed more often in small-seeded accessions. It should be mentioned that wet sprout weight was a transgressive character, interlinked not only with seed germination and germination energy, but also with seed weight, i.e., it depended on a coordinated variability in several sets of correlated characters.

Considering the distribution of the tested accessions across the space of the first two factors, it is possible to notice that the plants with similar characters are located close to each other (Fig. 3). Figure 3.1 shows a quite compact group of accessions reproduced at AES in 2017. Accessions grown at AES in 2015 are observed nearby. In the scatterplot they occupy the area characterized by high values of seed germination, seed germination energy, seed vigor, stem length, root length, leaf length, medium and large seeds, medium and high sprout weights.

Accessions reproduced at KES (2005) are in the area of plants with low or medium values of seed germination, germination energy, seed vigor, large and medium seeds, high and medium weights of dry and wet sprouts.

For a majority of accessions reproduced at AdES (2016), minimum levels of seed germination, germination energy and vigor were observed. Most of them are located in the area of small and medium seeds, small sprout weights, short

Table 7. Factor loadings of characters in mung bean seeds and sprouts Таблица 7. Факторная структура признаков семян и проростков маша

\begin{tabular}{|l|c|c|}
\hline \multicolumn{1}{|c|}{ Character } & Factor 1 & Factor 2 \\
\hline Germination energy of seeds & $\mathbf{0 . 8 5}$ & 0.17 \\
\hline 1000 seed weight & -0.05 & 0.55 \\
\hline Seed germination & $\mathbf{0 . 8 3}$ & -0.58 \\
\hline Seed hardness & -0.26 & -0.15 \\
\hline Seed vigor & $\mathbf{0 . 8 1}$ & 0.64 \\
\hline Wet sprout weight & 0.55 & $\mathbf{0 . 8 2}$ \\
\hline Dry sprout weight & 0.22 & 0.08 \\
\hline Sprout stem length & $\mathbf{0 . 8 3}$ & 0.04 \\
\hline Sprout root length & 0.62 & $\mathbf{0 . 7 3}$ \\
\hline Sprout stem diameter & -0.14 & 0.49 \\
\hline Sprout leaf length & 0.57 & 24.0 \\
\hline Variance, \% & 35.0 & \\
\hline
\end{tabular}


1

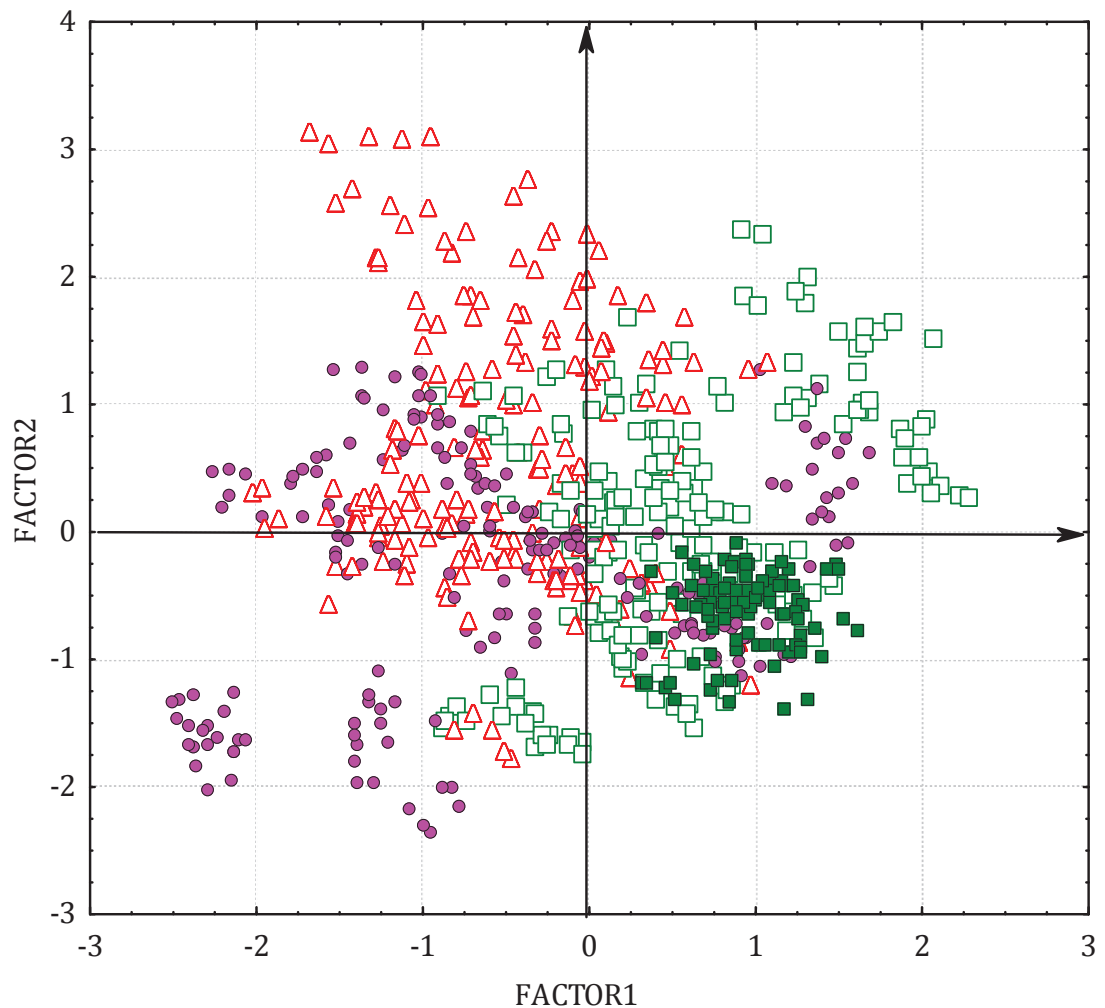

$\triangle 2005$, KES

2015, AES

- 2016, AdES

- 2017, AES

2

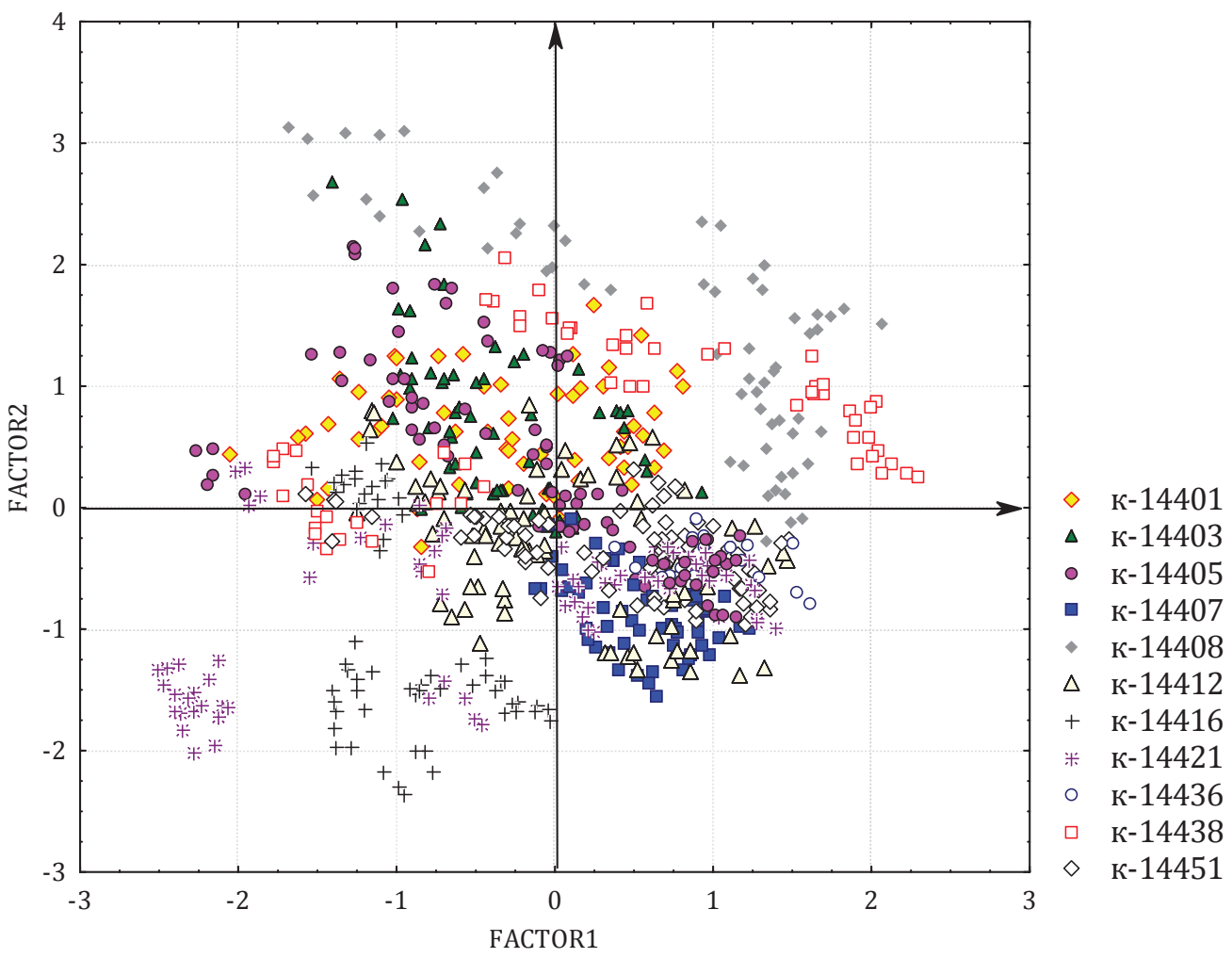

Fig. 3. Scatterplot of the tested mung bean accessions in the factorial space.

Factor 1, Factor 2 are the first two factors.

1. Across the stations, where 2005 means the seed reproduction at the Kuban Experiment Station (KES); 2015 and 2017 mean the seed reproductions at Astrakhan Experiment Station (AES); 2016 means the seed reproduction at Adler Experiment Station (AdES) of VIR.

2. Across VIR's catalogues, where 'k-' is the catalogue number of an accession

Рис. 3. Распределение изученных образцов маша в факторном пространстве.

Factor 1, Factor 2 - первые два фактора.

1. По станциям, где 2005 - репродукция Кубанской опытной станции; 2015 и 2017 - репродукции Астраханской опытной станции; 2016 - репродукция Адлерской опытной станции - филиалов ВИР.

2. По каталогам ВИР, где «К» - номер каталога 
leaves, stems and roots (in the scatterplot they are to the left, in the lower and middle parts). Accession k-14407 was an exception (on Fig. 3.1 it may be found among the accessions reproduced at AES in 2015 and 2017). This variety demonstrated high seed germination, germination energy and vigor, with medium values in sprout and seed weights, regardless of the year and place of seed reproduction. Accession k-14451 was close to the latter in the tested indicators. Also worth mentioning are k-14401, k-14403 and k-14408 which showed stable high levels in 1000 seed weight and sprout weights in all the years of testing. On the scatterplot they are in the upper part of the image (Fig. 3.2). Accessions k-14405 and k-14412 changed their indicators in different sites of reproduction: they demonstrated the best values of sprout weight when reproduced at KES, while their seed germination, germination energy and vigor were better at AES. Accession k-14416, with the highest percentage of hard seeds per sample (on Fig. 3.2, to the left in the lower and middle areas), had the lowest values in seed germination and seed vigor.

While analyzing Fig. 3, it is possible to trace a reduction of seed germination, germination energy and seed vigor levels when mung bean was cultivated in more humid environments (KES or AdES). These characters in a majority of accessions had high values when seed reproduction was performed in dry climate at AES. This is well in line with the data of other researchers, who reported that under higher humidity there was a decrease in seed germination because metabolic process tended to go faster, thus worsening the quality of seeds (Trisvyatsky, 1966; Adamova, 1971b). According to O. P. Adamova (Adamova, 1971a), when mung bean accessions were reproduced in Uzbekistan, their seed germination, like with other legume crops, was higher than in Abkhazia.

It should be also taken into account that higher humidity combined with higher temperatures accelerates the development of microorganisms on seed surface, which leads to even more rapid reduction and deterioration of seed germination (Maui, 2015; Kirik, Pikovsky, 2017). Accelerated development of microorganisms was registered during our experiments on the seeds reproduced at AdES: greater part of the seed material was affected by fungi and other diseases. So, it is natural that the germination of seeds at AdES was the lowest.

On the other hand, it is well known that the smaller are the seeds, the more active is their enzyme activity. Smallseeded plant forms possess more powerful and more stable vitality, and are able to retain their seed germination longer (Adamova, 1971b). The results of our research confirmed this fact: the larger seeds at KES had lower values of seed germination, germination energy and vigor that the smaller ones reproduced at AES.

Summarizing all of the abovementioned, it is possible to conclude that in our experiments the greatest effect on the tested characteristics was produced by specific individual features of accessions; the year, place and conditions of seed reproduction had lesser effects. It should be mentioned that, despite high variabilities of the studied morphological and physiological indicators and their dependence on the genotype and seed growing conditions, it was possible to identify mung bean varieties with stable and high levels of seed germination, germination energy and vigor, combined with medium sprout weight values: $\mathrm{k}-14407$ and $\mathrm{k}-14451$. As for accessions k-14401, k-14403 and k-14408, they are the best in terms of economic value, as they demonstrated the highest sprout weights, regardless of the site of seed reproduction.

\section{Conclusion}

The accessions of Vigna radiata from Kenya demonstrated high variability in morphological, agronomic and physiological characteristics of their seeds and sprouts. A statistically significant effect on all these variable characters was produced by the genotype, the year of seed reproduction, and the ecogeographic environments where the seeds were formed. Individual features of the accessions provided the strongest effect on all characteristics; the effect of the site of reproduction and meteorological conditions (precipitation amounts and sums of active temperatures) was less strong. Abundant rainfalls during the plant growing season reduced the sowing qualities of seeds. The dry climate of Astrakhan Province proved to be more favorable for mung bean cultivation.

The effect of weather conditions, recorded during the growing season, on the variability of morphological characters in mung bean sprouts was weaker than on the seed germination indicators.

The weight of a mung bean sprout is interrelated with seed germination energy, stem length and diameter, and leaf length. Seed hardness is negatively correlated with seed germination, germination energy, and seed vigor, and positively correlated with small seed size.

Among the studied accessions, there are mung bean varieties with high and stable indicators of seed germination, germination energy, and seed vigor, morphological characteristics, and weight of sprouts. These varieties are promising for large-scale commercial cultivation of mung bean for microgreen production.

This study was implemented within the framework of the State Task in accordance with the topical plan of VIR for Project No. 0662-2019-0002 "Scientific support for effective utilization of the global genetic diversity of grain legume crops and their wild relatives from the VIR collection".

Работа выполнена в рамках государственного задания согласно тематическому плану ВИР по проекту № 0662-2019-0002 «Научное обеспечение эффективного использования мирового генофонда зернобобовых культур и их диких родичей коллекции ВИР».

\section{References/Литература}

Adamova O.P. Effect of conditions of growing pulses on seed formation. Bulletin of Applied Botany, Genetics and Plant Breeding. 1971a;45(3):151-160. [in Russian] (Адамова 0.П. Влияние условий выращивания зерновых бобовых на формирование семян. Труды по прикладной ботанике, генетике и селекции. 1971a;45(3):151-160).

Adamova O.P. Some biological characters of pulse seeds. Bulletin of Applied Botany, Genetics and Plant Breeding. 1971;45(3):145-150. [in Russian] (Адамова О.П. Некоторые биологические особенности семян бобовых. Труды по прикладной ботанике, генетике и селекции. 1971b;45(3):145-150).

Ebert A. High value specialty vegetable produce. In: K.V. Peter, P. Hazra (eds). Handbook of Vegetables. Houston, USA: Studium Press LLC; 2015:p.119-143.

Ivanter E.V., Korosov A.V. Introduction to quantitative biology (Vvedeniye v kolichestvennuyu biologiyu). Petrozavodsk; 2003. [in Russian] (Ивантер E.B., Коросов А.В. Введение в количественную биологию. Петрозаводск; 2003). 
Kirik M., Pikovsky M. Diagnostics of diseases of seeds of peas and soybeans (Diagnostika hvorob nasinnya gorohu ta soi). Propozitsiya =Proposition. 2017;(1):116-120. [in Ukrainian] (Кирик М., Піковський М. Діагностика хвороб насіння гороху та сої. Пропозиція. 2017;(1):116-120).

Kyriacou M.C., Rouphael Y., Di Gioia F., Kyratzis A., Serio F., Renna M. et al. Micro-scale vegetable production and the rise of microgreens. Trends in Food Science and Technology. 2016;57:103-115. DOI: 10.1016/j.tifs.2016.09.005

Likhachev B.S. Determination of seed vigor of grain crops by morphological and physiological assessment of sprouts: methodological guidelines (Opredeleniye sily rosta semyan zernovykh kultur po morfo-fiziologicheskoy otsenke prorostkov: metodicheskoye ukazaniye). Leningrad: VIR; 1975. [in Russian] (Лихачев Б.С. Определение силы роста семян зерновых культур по морфо-физиологической оценке проростков: методическое указание. Ленинград, ВИР; 1975).

Likhachev B.S. Interrelation between seed vigor and growth, development and productivity of plants grown of them. Bulletin of Applied Botany, Genetics and Plant Breeding. 1984;89:81-88. [in Russian] (Лихачев Б.С. Связь силы роста семян с ростом, развитием и продуктивностью формирующихся из них растений. Труды по прикладной ботанике, генетике и селекции. 1984;89:81-88)

Likhachev B.S., Shevchenko Z.N. About the variation in germination of pea and chickpea seeds (O raznokachestvennosti prorastaniya semyan gorokha i nuta). Bulletin of the N.I. Vavilov All-Union Research Institute of Plant Industry. 1975;53:69-72. [in Russian] (Лихачев Б.С., Шевченко 3.Н. О разнокачественности прорастания семян гороха и нута. Бюллетень Всесоюзного НИИ растениеводства им. Н.И. Вавилова. 1975;53:69-72).

Market Access Database. European Commission. 2018. Available from: http://madb.europa.eu/madb/statistical_form.htm [accessed Apr. 2, 2020].

Maui A.A. Disease of soybean seeds and their control measures. Science Almanac. 2015;2(4):163-166. [in Russian] (Мауи А.А. Болезни семян сои и меры борьбы с ними.
Научный альманах. 2015;2(4):163-166). DOI: 10.17117/ na.2015.02.163

Pataczek L., Zahir Z.A., Ahmad M., Rani S., Nair R., Schafleitner R. et al. Beans with benefits - The role of mungbean (Vigna radiata) in a changing environment. American Journal of Plant Sciences. 2018;9(7):1577-1600. DOI: 10.4236/ajps.2018.97115

Rakovskaya N.V., Zabegaeva O.N., Dzyubenko E.A. Seed quality evaluation in the collection of Cyamopsis tetragonoloba after long-term storage under uncontrolled conditions. Proceedings on Applied Botany, Genetics and Breeding. 2019;180(4):48-58. [in Russian] (Раковская Н.В., Забегаева О.Н., Дзюбенко Е.А. Оценка качества семян циамопсиса четырехкрыльникового при длительном хранении в неконтролируемых условиях. Труды по прикладной ботанике, генетике и селекции. 2019;180(4):48-58). DOI: 10.30901/2227-88342019-4-48-58

RIHMI-WDC. Technology of Aisori: Site of technology (FGBU “VNIIGMI-MTsD”. Tekhnologii Aisori: sayt tekhnologii). 2014. [in Russian] (ФГБУ «ВНИИГМИ-МЦД». Технологии Аисори: сайт технологии. 2014) URL: http://meteo.ru/it/178-aisori [дата обращения: 25.04.2018].

Shi Z., Yao Y., Zhu Y., Ren G. Nutritional composition and antioxidant activity of twenty mung bean cultivars in China. The Crop Journal. 2016;4(5):398-406. D0I: 10.1016/j. cj.2016.06.011

Tang D., Dong Y., Ren H., Li L., He C. A review of phytochemistry, metabolite changes, and medicinal uses of the common food mung bean and its sprouts (Vigna radiata). Chemistry Central Journal. 2014;8(1):4. DOI: 10.1186/1752153X-8-4

Trisvyatsky L.A. Grain storage (Khraneniye zerna). Moscow; 1986. [in Russian] (Трисвятский Л.А. Хранение зерна. Москва; 1986).

Ullah R., Ullah Z., Al-Deyab S.S., Adnan M., Tariq A. Nutritional assessment and antioxidant activities of different varieties of Vigna radiata. The Scientific World Journal. 2014;(4);871753. DOI: 10.1155/2014/871753
Прозрачность финансовой деятельности / The transparency of financial activities

Авторы не имеют финансовой заинтересованности в представленных материалах или методах.

The authors declare the absence of any financial interest in the materials or methods presented.

\section{Для цитирования / How to cite this article}

Сушкевич А.В., Забегаева О.Н., Бурляева М. О. Влияние условий выращивания и года репродукции на посевные качества семян и морфофизиологические показатели проростков Vigna radiata (L.) R. Wilczek. Труды по прикладной ботанике, генетике и селекции. 2020;181(2):73-86. DOI: 10.30901/2227-88342020-2-73-86

Sushkevich A.V., Zabegaeva O.N., Burlyaeva M.O. The effect of growing conditions and the year of reproduction on sowing qualities of seeds, morphological and physiological characteristics in sprouts of Vigna radiata (L.) R. Wilczek. Proceedings on Applied Botany, Genetics and Breeding.2020;181(2):73-86.DOI:10.30901/2227-8834-2020-2-73-86
Авторы благодарят рецензентов за их вклад в экспертную оценку этой работы / The authors thank the reviewers for their contribution to the peer review of this work

\section{Дополнительная информация / Additional information}

Полные данные этой статьи доступны / Extended data is available for this paper at https://doi.org/10.30901/2227-8834-2020-2-73-86

Мнение журнала нейтрально к изложенным материалам, авторам и их месту работы / The journal's opinion is neutral to the presented materials, the authors, and their employer

Все авторы одобрили рукопись / All authors approved the manuscript

Конфликт интересов отсутствует / No conflict of interest 